\title{
Suckling induced insulin-like growth factor-1 (IGF-1) release in mother rats
}

\author{
András H. Lékó ${ }^{\mathrm{a}, \mathrm{b}}$, Melinda Cservenák ${ }^{\mathrm{a}, \mathrm{c}}$, Árpád Dobolyi ${ }^{\mathrm{a}, \mathrm{b}, \mathrm{c}, *}$ \\ a Laboratory of Neuromorphology, Department of Anatomy, Histology and Embryology, Semmelweis University, Budapest 1094, Hungary \\ b MTA-ELTE Laboratory of Molecular and Systems Neurobiology, Department of Physiology and Neurobiology, Hungarian Academy of Sciences and Eötvös Loránd \\ University, Budapest 1117, Hungary \\ ${ }^{c}$ MTA-ELTE NAP B Laboratory of Molecular and Systems Neurobiology, Hungarian Academy of Sciences and Eötvös Loránd University, Budapest 1117, Hungary
}

\section{A R T I C L E I N F O}

\section{Keywords:}

Lactation

Prolactin

IGF-1

$\mathrm{GH}$

IGFBPs

Neuropeptides

\begin{abstract}
A B S T R A C T
Objective: Lactation involves significant neuroendocrine changes. The elevated prolactin (PRL) release from the pituitary, induced markedly by suckling, is the most relevant example. Suckling also causes a significant and rapid elevation in growth hormone $(\mathrm{GH})$ levels. GH is necessary for milk synthesis as milk yield is stopped completely in the absence of PRL and GH, while the absence of PRL alone causes only a 50\% reduction. Insulinlike growth factor-1 (IGF-1) plays an important role in the GH axis. GH exerts its effects through IGF-1 in the periphery, for example in the mammary gland. In addition, IGF-1 is responsible for the long-loop feedback control of GH secretion.

Design: IGF-1 secretion has not been established yet in mothers. Therefore, in the present study, we investigated the effect of suckling on serum IGF-1 level in rat mothers and correlated it with serum PRL levels. We examined a potential mechanism of the regulation of IGF-1 level during suckling by administering IGF-1 into the lateral ventricle of rat mothers continuously for 12 days, or acutely, right before the start of suckling.

Results: We described that suckling affected IGF-1 release based on one-way repeated measures ANOVA $(\mathrm{F}=10.8$ and $p<0.001)$ and caused a marked increase of IGF-1 level $30 \mathrm{~min}$ after the start of suckling $(p<0.001)$. We demonstrated a significant $(p<0.05$; the correlation coefficient was 0.29$)$ correlation to PRL level during suckling which supports that PRL could induce IGF-1 release. The prolonged central IGF-1 administration diminished the suckling-induced IGF-1 surge ( $\mathrm{F}=9.19$ and $p<0.001)$ while the acute treatment did not have any effect compared to artificial cerebrospinal fluid injection, analysed with two-way repeated measures ANOVA.

Conclusions: In conclusion, suckling induces IGF-1 release either by elevating PRL or GH. Long-loop feedback via IGF-1 in the GH axis can diminish this action.
\end{abstract}

\section{Introduction}

Lactation is a physiological state characterized by hormonal changes, such as marked alterations in prolactin (PRL), gonadal steroid and growth hormone (GH) levels. GH is suggested to play an important role in the maintenance of lactation in the rat: milk yield is reduced by approximately $50 \%$ in the absence of PRL while milk yield is totally stopped in the absence of PRL and GH [1]. GH is necessary for the synthesis of milk with normal composition including its effect on the uptake of nutrients used for milk synthesis and secretory cell activity [2]. It is also known that GH treatment enhances milk production in human, too [3]. These lactation-promoting effects of GH are in line with the suckling-induced GH release: plasma GH significantly increases after the return of the pups in rats and pigs [4-6]. Inhibition of GHRH or naloxone can suppress the suckling-induced increase in GH plasma level [7], although the regulation of this process remains to be determined.

GH released from the pituitary stimulates the expression of insulinlike growth factor-I (IGF-1) in the liver and other peripheral tissues, as IGF-1 is the main mediator of the actions of GH. GH is ineffective by acting directly on mammary tissue, whereas IGF-1 stimulates milk yield, supporting the important impact of IGF-1 on lactation. IGF-1 increased blood flow to the mammary gland as well as milk synthesis $[8,9]$. IGF-1 is as an important survival signal for the lobular-alveolar mammary epithelial cells. Its expression, together with that of Insulinlike growth factor binding protein-3 (IGFBP-3), is elevated during lactation in these cells $[10,11]$. Furthermore, they can modify the involution process in late lactation by promoting the survival of the cells

\footnotetext{
* Corresponding author at: MTA-ELTE NAP B Laboratory of Molecular and Systems Neurobiology, Department of Physiology and Neurobiology, Hungarian Academy of Sciences and Eötvös Loránd University, Budapest, 1117, Hungary.

E-mail address: dobolyia@caesar.elte.hu (Á. Dobolyi).
} 
in a transgenic overexpression model $[10,11]$. IGF-1 can also act in the mammary gland as a paracrine factor, because GH affects stroma cells to produce IGF-1 which can promote the survival of epithelial cells [12]. Nevertheless, the IGF-1 plasma level during suckling remained to be determined. Not only pituitary GH but also PRL can increase circulating IGF-1 levels, acting directly within the liver. In hypophysectomised rat, single injection of PRL resulted in a moderate increase in serum IGF-1 level and a 15-fold increase in hepatic IGF-1 mRNA expression [13]. Correlation between IGF-1 and PRL levels during suckling has not been investigated, although suckling induces PRL release from the pituitary, and can in turn affect circulating IGF-1 levels.

IGF-1 plays an important role in the long-loop feedback control of GH release, too. Intracerebroventricular (icv.) administration of IGF-1 results in a decrease in GH pulse amplitude, in hypothalamic GHRH synthesis and secretion, and an increase in hypothalamic somatostatin expression [14,15]. In humans, sustained IGF-1 infusion causes a reduction in GH pulse frequency [16]. In addition, we showed in our previous study that prolonged icv. IGF-1 treatment induced tyrosinehydroxylase expression and phosphorylation in the tuberoinfundibular dopaminerg neurons of the arcuate nucleus [17]. The enhanced dopamine release from these neurons suppressed suckling-induced PRL release from the pituitary, and pup weight gain, suggesting reduced lactation [17]. We addressed the effect of centrally administered IGF-1 on IGF-1 serum level during suckling in the present study, to test if IGF-1 can act as a feedback signal.

In the present study, we measured IGF-1 plasma levels in response to suckling and also correlated it with PRL levels. In addition, we injected icv. IGF-1 acutely via cannulas and also used prolonged icv. Administration via osmotic minipumps connected to brain infusion kits, to examine its effect on plasma IGF-1 level during suckling in mother rats.

\section{Materials and methods}

\subsection{Animals}

All animal experimentations were approved by the Animal Examination Ethical Council of the Animal Protection Advisory Board at the Semmelweis University, Budapest, and met the guidelines of the Animal Hygiene and Food Control Department, Ministry of Agriculture, Hungary. A total of 41 female Wistar rats (250-300 g adult body weight; Charles Rivers Laboratories, Budapest, Hungary) were used in this study. Animals were kept on standard laboratory conditions at a temperature of $22 \pm 1{ }^{\circ} \mathrm{C}$, with 12-h light, 12-h dark periods (lights on at 06:30), and supplied with dry rat food and drinking water ad libitum. For mating, two female and a male rat were kept in a cage for 7 days. After that, potentially pregnant female rats as well as lactating rat dams with litters were kept in cages individually. Rats were anesthetized between 9 and $10 \mathrm{AM}$ with an intramuscular injection of anaesthetic mix containing $0.3 \mathrm{ml} / 300 \mathrm{~g}$ body weight ketamine $(67 \mathrm{mg} / \mathrm{kg})$ and $0.2 \mathrm{ml} / 300 \mathrm{~g}$ body weight xylazine $(13 \mathrm{mg} / \mathrm{kg})$ before implantation of osmotic minipumps, icv. cannula or jugular cannula.

\subsection{Implantation of jugular cannula}

On the 13th postpartum day, rat dams received 25-mm-long sterile polyethylene jugular cannulas (Plastics One) under ketamine-xylazine anaesthesia as described above [18]. The cannulas were filled with heparinized saline to prevent clotting of the blood.

\subsection{Blood sampling before and during suckling}

On the following day, we obtained blood $-0.3 \mathrm{ml}$ each time - via jugular cannulas to measure serum PRL and IGF-1 levels in response to suckling: first before taking away the pups for $4 \mathrm{~h}$, second before returning the pups (baseline control) and also at 15, 30, 60 min after the return of the pups. The volume of blood taken was $0.3 \mathrm{ml}$ each time, and the same amount of heparinized saline was injected back into the circulation. Blood was centrifuged at $4{ }^{\circ} \mathrm{C}$ for $10 \mathrm{~min}$ at $12.000 \mathrm{~g}$ and the supernatant was stored at $-20{ }^{\circ} \mathrm{C}$ for hormone assays.

\subsection{Measurement of PRL and IGF-1 levels with hormone assays}

Serum PRL level was measured with RIA, which was processed as described previously [18]. IGF-1 level was measured by ELISA with the Thermo Scientific $^{\mathrm{TM}}$ Pierce $^{\mathrm{TM}}$ Rat IGF-1 ELISA Kit (Thermo Scientific, Frederick, MD, USA) according to the protocol suggested by the manufacturer.

\subsection{Implantation of icv. cannulas, osmotic minipumps and brain infusion} kits

Osmotic minipumps injecting continuously for 14 days (ALZET Micro-Osmotic Pump Model 2002, Durect ${ }^{\mathrm{TM}}$, Cupertino, CA, USA), loaded with IGF-1 ( $4 \mu \mathrm{g} / \mu \mathrm{l} ; 48 \mu \mathrm{g}$ IGF-1/day, PeptideSciences $\left.{ }^{\mathrm{TM}}\right)$ or artificial cerebrospinal fluid (ACSF; $147 \mathrm{mM} \mathrm{NaCl}, 3.5 \mathrm{mM} \mathrm{KCl}, 2 \mathrm{mM}$ $\mathrm{CaCl} 2, \quad 1 \mathrm{mM} \mathrm{MgCl} 2, \quad \mathrm{pH}=7.2)$ and connected to intracerebroventricular cannulas were used in rat dams $(n=7-7)$. For icv. implantation of the cannulas, rats were anesthetized as described above, and fixed in a stereotaxic apparatus. The skin was cut over the skull and a hole of about $1 \mathrm{~mm}$ diameter was drilled into the left side of the skull above the lateral ventricle positioned at the following coordinates: anteroposterior, -0.5 ; lateral, 1.4 ; ventral, $3.6 \mathrm{~mm}$ from the bregma. Cannulas (ALZET Brain Infusion Kit 2, Durect ${ }^{\mathrm{TM}}$ ) were inserted into the lateral ventricle and fixed to the skull with cranioplastic cement on the 2nd postpartum day. The pumps were placed subcutaneously (s.c.) at the back of the animal. After the operation, Tardomyocel ${ }^{\circledR}$ comp. III antibiotics $(0.1 \mathrm{ml} / \mathrm{kg}$ body weight) was given s.c. to the animals for 5 days to prevent infections. On the 4th postpartum day, icv. cannulas were implanted in 13 additional rat dams to investigate acute effects as described previously [19]. On the day of blood sampling during suckling, IGF-1 $(0.2 \mu \mathrm{g} / \mu \mathrm{l}$, a total of $5 \mu \mathrm{l}$ injected for $5 \mathrm{~min}$ ) or ACSF was administered icv. Starting at $5 \mathrm{~min}$ before the return of the pups.

\subsection{Statistical analysis}

Statistical analysis was performed with Statistica 13.2 Software (Dell Inc., Round Rock, TX, USA). Normality was tested with ShapiroWilk's test. We used one-way repeated measures ANOVA and Dunnett's post-hoc analysis to describe the effect of suckling on serum IGF-levels. Spearman's rank correlation was used to detect the correlation between serum PRL and IGF-1 levels during suckling. We performed two-way repeated measures ANOVA and Newman-Keuls post-hoc analysis to test whether the acute or chronic icv. IGF-1 administration affects serum IGF-1 levels. Levene's test was used to examine the homology of variances before the two-way repeated measures ANOVA.

\section{Results}

\subsection{Suckling-induced IGF-1 elevation}

IGF-1 and PRL levels were measured on the 14th day postpartum in lactating rat dams $(n=14)$ (Fig. 1$)$. At $8 \mathrm{AM}$, that is $4 \mathrm{~h}$ before the removal of the pups, serum IGF-1 concentration was $69.38 \pm 8.10 \mathrm{ng} /$ $\mathrm{ml}$ while PRL level was $142.86 \pm 14.30 \mathrm{ng} / \mathrm{ml}$. Separation of the pups did not cause any significant effect on IGF-1 concentration as it was $72.63 \pm 4.39 \mathrm{ng} / \mathrm{ml}$ at the end of isolation, whilst PRL level decreased to a basal $12.46 \pm 2.30 \mathrm{ng} / \mathrm{ml}$ level in the serum. After the return of the pups, suckling started immediately. Suckling induced PRL release as its serum level started to rise significantly after $15 \mathrm{~min}$ and reached a peak at $30 \mathrm{~min}$ : $138.16 \pm 22.33 \mathrm{ng} / \mathrm{ml}$ (after $15 \mathrm{~min}$ ), 


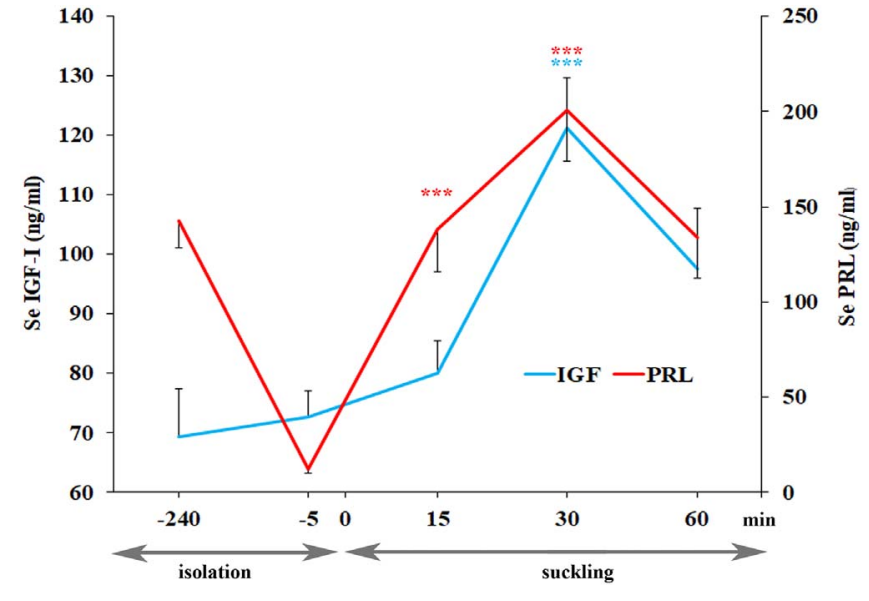

Fig. 1. Suckling-induced IGF-1 and PRL elevation

The diagram shows serum IGF-1 and PRL levels during the isolation-suckling protocol. The $\mathrm{x}$-axis shows time in a nonlinear fashion. Below the $\mathrm{x}$-axis, the periods of pup separation and suckling are indicated with gray arrows. IGF-1 serum concentration did not change during the isolation of pups, whilst PRL decreased to a minimal level. Suckling induced a significant elevation of the IGF-1 level at $30 \mathrm{~min}$ and of the PRL level at 15 and $30 \mathrm{~min}$ after the return of the pups compared to the level right before the return, analysed with Dunnett post-hoc test $(* * *=p<0.001)$.

$200.98 \pm 27.28 \mathrm{ng} / \mathrm{ml}$ (after $30 \mathrm{~min}$ ), $133.83 \pm 21.08 \mathrm{ng} / \mathrm{ml}$ (after $60 \mathrm{~min}$ ). IGF-1 serum concentration also showed a significant increase in response to suckling, with a maximum after $30 \mathrm{~min}$ : $79.98 \pm 5.56 \mathrm{ng} / \mathrm{ml}$ (after $15 \mathrm{~min}$ ), $121.18 \pm 8.53 \mathrm{ng} / \mathrm{ml}$ (after $30 \mathrm{~min}$ ), and $97.65 \pm 10.08 \mathrm{ng} / \mathrm{ml}$ (after $60 \mathrm{~min}$ ). Suckling had a significant effect on the serum IGH-1 level as established with one-way repeated measures ANOVA ( $\mathrm{F}=10.8, p<0.001)$. The increases in the serum levels of both hormones were significant after return of the pups as compared to the levels before the return of the pups $(p<0.001$ at 15 and $30 \mathrm{~min}$ in PRL level, and $p<0.001$ at $30 \mathrm{~min}$ in IGF-1 level) as established with Dunnett post-hoc analysis.

\subsection{Serum IGF-1 level correlates with PRL during suckling}

We examined the correlation between the IGF-1 and PRL levels during suckling (Fig. 2.). We found a significant $(p<0.05)$ correlation between suckling-induced serum IGF-1 and PRL levels with Spearman rank correlation. The correlation coefficient was 0.29 .

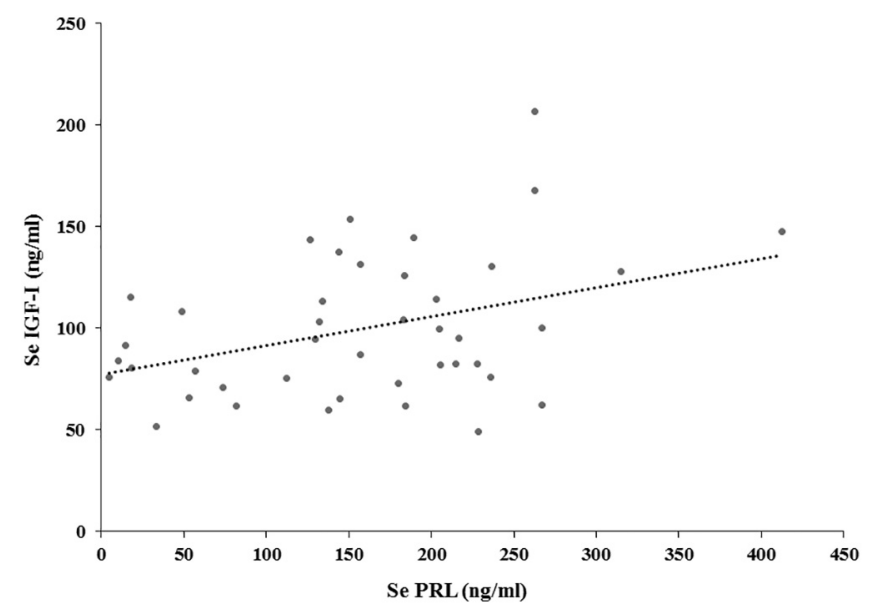

Fig. 2. Serum IGF-1 correlates with PRL during suckling

The scatterplot shows IGF-1 and PRL serum concentrations from measurements during the suckling period at 15, 30, $60 \mathrm{~min}$ after the return of the pups. Each plot represents a single blood sample, in which both IGF-1 and PRL levels were measured. We established a significant positive correlation between IGF-1 and PRL levels during suckling.

\subsection{Prolonged icv. IGF-1 administration diminishes suckling-induced IGF-1 surge}

We examined the effects of continuous icv. IGF-1 administration on the suckling-induced IGF-1 surge (Fig. 3). Rat mothers $(n=7)$ received IGF-1 icv. $(4 \mu \mathrm{g} / \mu \mathrm{l} ; 48 \mu \mathrm{g}$ IGF-1/day) or ACSF $(\mathrm{n}=7)$ via osmotic minipumps connected to brain infusion kits continuously for 12 days. We examined the suckling-induced IGF-1 surge on the 14th day postpartum in the above described isolation-suckling protocol. Serum IGF-1 concentrations were as follows in $\mathrm{ng} / \mathrm{ml}$ : $88.31 \pm 9.46$ (before isolation), $91.32 \pm 8.72$ (before the return of pups), $78.5 \pm 9.14$ (15 min after the return of the pups), $149.74 \pm 9.97$ (after $30 \mathrm{~min}$ ), and $77.51 \pm 6.05$ (after $60 \mathrm{~min}$ ) in the control group, while $100.33 \pm 9.49$ (before isolation), $95.34 \pm 9.53$ (before return of pups), $104.3 \pm 7.57$ (after $15 \mathrm{~min}$ ), $110.13 \pm 9.03$ (after $30 \mathrm{~min}$ ) and $128.07 \pm 10.16$ (after $60 \mathrm{~min}$ ) in the IGF-1-treated group. Analysis of the results with two-way repeated measures ANOVA revealed that both suckling $(p<0.001)$ and treatment $(p<0.001)$ had significant effect on the serum IGF-1 levels. Using post-hoc analysis, we could also establish that suckling caused a marked surge at $30 \mathrm{~min}$ in the control group: it was significant compared to the level before suckling $(p<0.001)$ and to the level of IGF-treated group in the same time $(p<0.01)$. There was a delay in the IGF-treated group and a less significant surge at $60 \mathrm{~min}$. Serum IGF-1 concentration of the treated group at $60 \mathrm{~min}$ was significantly higher compared to the level before suckling $(p<0.05)$ and to the level of control group at the same time point $(\mathrm{p}<0.01)$. Post-hoc analyses were conducted with NewmanKeuls test.

3.4. Acute IGF-1 icv. administration has no effect on suckling-induced IGF1 increase

We also addressed the possible rapid effect of icv. IGF-1 on sucklinginduced IGF-1 and PRL increases. We administered icv. IGF-1 $(0.2 \mu \mathrm{g} /$ $\mu \mathrm{l}$, total of $5 \mu \mathrm{l} / \mathrm{animal}$ ) or ACSF as control to rat mothers ( $n=7$ and 6 , respectively) $5 \mathrm{~min}$ before the return of the pups in the same experimental protocol of isolation and suckling as described above (Fig. 4). The treatment did not have any effect on the suckling-induced elevation of IGF-1 and PRL levels, which were both significant $(p<0.05)$ at $15 \mathrm{~min}$ after the return of the pups as compared to the levels at the end of isolation based on Newman-Keuls post-hoc analyses. Serum IGF-1 concentrations in $\mathrm{ng} / \mathrm{ml}$ were $51.4 \pm 7.79, \quad 53.54 \pm 5.25$, $83.82 \pm 8.44,86.66 \pm 10.14$ and $97.12 \pm 10.82$ in IGF-1 treated mothers, and $54.09 \pm 10.21, \quad 48.2 \pm 4.65, \quad 78.16 \pm 7.55$, $93.16 \pm 12.47$ and $96.06 \pm 8.33$ in the control group. Serum PRL levels in $\mathrm{ng} / \mathrm{ml}$ were as follows: $108.16 \pm 17.2,15.25 \pm 3.92$, $102.87 \pm 36.92,146.4 \pm 33.53,115.2 \pm 29.98$ in IGF-1 treated mothers, and $124.68 \pm 6.33,19.48 \pm 6.03, \quad 118.42 \pm 31.97$, $139.15 \pm 49.55,135.48 \pm 23.84$ in the control mothers, respectively.

\section{Discussion}

The significant suckling-induced elevation of serum IGF-1 level, which was established at $30 \mathrm{~min}$ after the beginning of suckling, was a major novel finding of the study. Although there is no difference in the basal IGF-1 level between lactating and non-lactating rat dams [20], return of the pups after a $4 \mathrm{~h}$ long isolation caused a rapid onset of suckling and a later a significant IGF-1 surge. The time course of increase in IGF-1 level was similar to the increase in GH and in PRL levels [7] in response to suckling. PRL concentration elevated earlier, there was a significant change as compared to its basal level detected at the end of isolation period even at $15 \mathrm{~min}$ after the onset of suckling. The induction of IGF-1 was slower, but it reached its maximum at $30 \mathrm{~min}$, like the PRL surge did. In addition, during the suckling period, we found a significant correlation between serum PRL and IGF-1 levels, which 


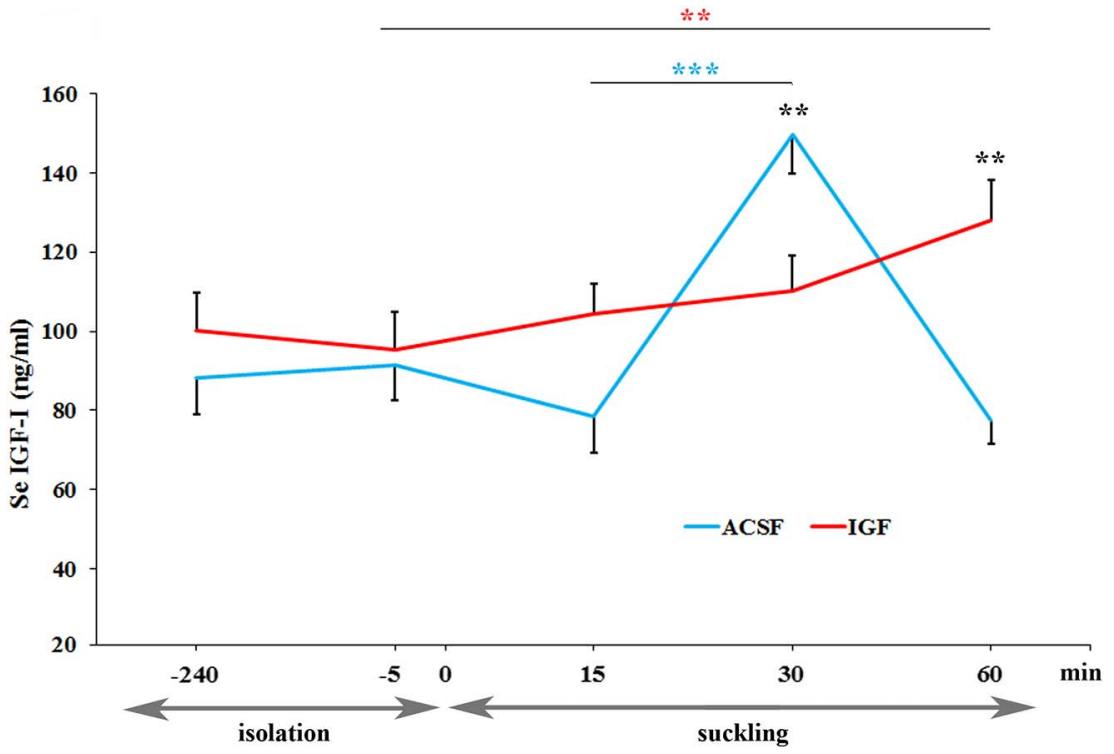

Fig. 3. Continuous icv. IGF-1 diminishes the suckling-induced IGF-1 surge

The diagram shows serum IGF-1 levels during the isolation-suckling protocol. The $\mathrm{x}$-axis shows time in a nonlinear fashion. Below the $\mathrm{x}$ axis, the periods of pup separation and suckling are indicated with gray arrows. suggests that it might be an association between these two hormones. We assume that the most probable source of the rapid increase of serum IGF-1 level might be its secretion from the liver, because this organ contributes approximately $70 \%$ of the total circulating IGF-1 [21]. Other peripheral tissues can also produce IGF-1, but mainly for autocrine and paracrine purposes [22]. Suckling can stimulate IGF-1 either via GH or PRL. On the one hand, the GHRH dependent, suckling-induced GH release [7] can induce IGF-1 release either from the liver or from other peripheral tissues including the mammary gland [23]. On the other hand, PRL can also increase circulating IGF-1 levels acting directly within the liver [13], although these results are somewhat inconsistent in the literature. English et al. found that hepatic portal vein infusion of PRL stimulated the growth of the mammary lobulo-alveolar system more than external jugular vein infusion did, but it was not effective in elevating serum IGF-1 concentrations [24]. PRL could influence IGF-1 concentration by altering the level of IGF binding proteins, too. Thus, PRL elevated IGFBP-3 and decreased IGFBP-1 and 2 levels by changing their hepatic expression $[25,26]$. IGFBP-3 is the major carrier protein of IGF-1 in the circulation, which can also

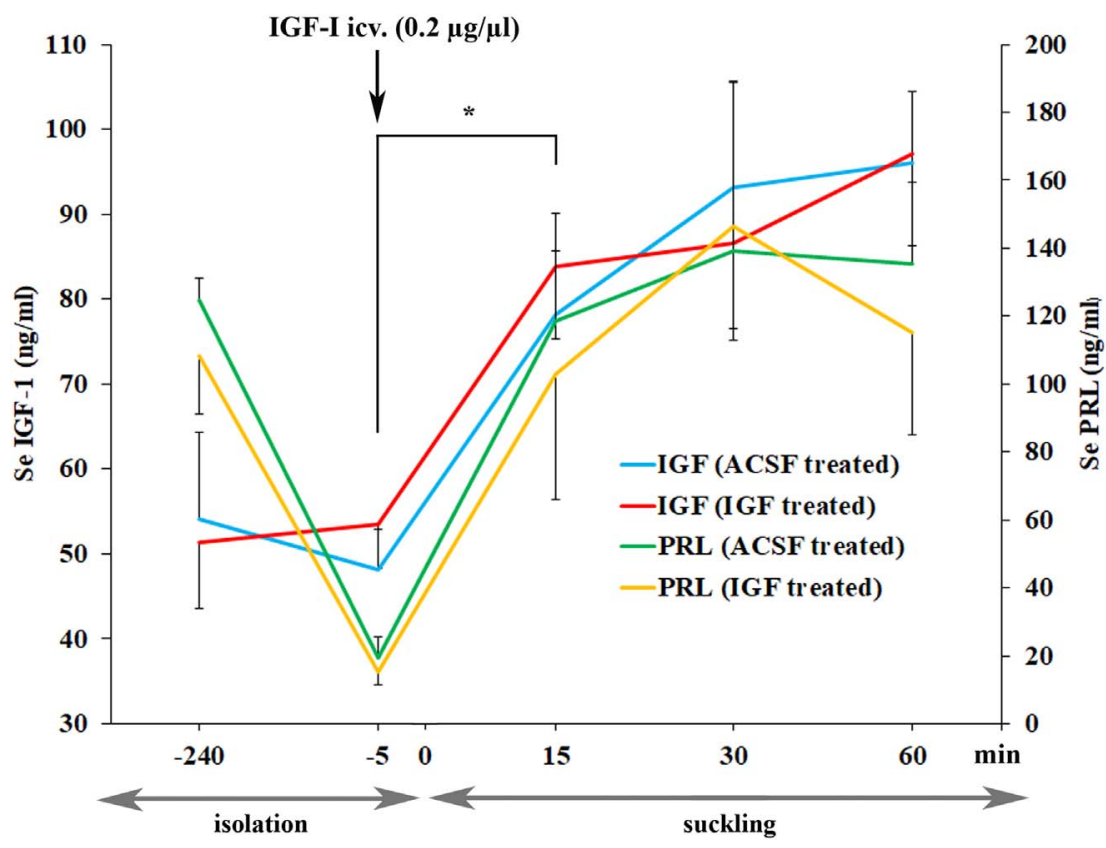

elongatethe half-life of IGF-1. Therefore, if GH or PRL treatment of lactating cows results in an increase of IGFBP-3 serum level [27], they could contribute to an elevated IGF-1 level as well.

The suckling-induced IGF-1 release may have a physiological importance because circulating IGF-1 promotes lactation via different routes. First, IGF-1 can facilitate PRL release from the pituitary through its receptors on lactotroph cells $[28,29]$. Second, IGF-1 increases milk synthesis in association with mammary blood flow $[8,9]$. Furthermore, overexpression of IGF-1 inhibits mammary cell apoptosis during late lactation [10]. Histological analysis of mammary tissue from IGF-1overexpressing mice showed incomplete mammary involution [11], ductile hypertrophy [30] and some enhancement of milk yield was also observed [16]. IGF-1 may enhance the intracellular signal transduction of PRL, too, as both rat and bovine explant cultures showed rapid stimulation of Stat5 by IGF-1 at high concentrations typically used in explant cultures as well as at levels within physiologic ranges [31].

We investigated possible regulatory mechanisms in the background of suckling-induced IGF-release. Chronic icv. IGF-administration delayed the IGF-surge as suckling did not cause any induction in
Fig. 4. Acute icv. IGF-1 administration does not affect suckling-induced IGF-1 and PRL increase

The diagram shows serum IGF-1 and PRL levels during the isolationsuckling protocol. The $\mathrm{x}$-axis shows time in a nonlinear fashion. Below the x-axis, the periods of pup separation and suckling are indicated with gray arrows. 
circulating IGF-1 levels at $30 \mathrm{~min}$ after the beginning of suckling in the presence of exogenously supplied IGF-1. Although there was a significant increase after $60 \mathrm{~min}$, our data are not sufficient to establish firmly whether it is a surge or not, because we do not have information on later time points. Central IGF-1 can exert this effect in the hypothalamus either by acting as a long-loop negative feedback modulator of GH axis or by suppressing suckling-induced PRL release. IGF-1 is responsible for the long-loop feedback in the GH-IGF axis. IGF-1 receptor is expressed throughout the hypothalamus, including the arcuate nucleus, dorsal and ventromedial nuclei of the hypothalamus, and the median eminence [32], so central administration of IGF-1 can affect neuroendocrine functions via receptors in all these brain regions. According to Abe et al., icv. administration of IGF-1, $2 \mathrm{~h}$ prior to experiments, results in a decrease in GH pulse amplitude [14]. The GH-pulse is largely dependent on hypothalamic GHRH release [33]. Therefore, the discovery by Sato et al. that continuous icv. infusion of IGF-1 for 7 days decreased GHRH mRNA in the rat while somatostatin mRNA levels were increased supports a GH mediated effect of IGF-1. Furthermore, decrease in GHRH mRNA levels was greater in female than in male rats [15]. Consequently, IGF-1 can act at the gene expression level on GHRH and somatostatin, and in turn on suckling-induced GH-release. We established in our previous study that prolonged icv. administration of IGF-1 in the postpartum period suppressed sucklinginduced PRL release [17]. IGF-1 induced the expression of tyrosinehydroxylase enzyme in the tuberoinfundibular dopaminergic neurons of the arcuate nucleus. Therefore, these neurons produce more dopamine, which in turn inhibits PRL release from the pituitary and consequently, the IGF-1 inducing effect of PRL attenuates [17]. All these findings are concordant with our novel results: while prolonged icv. IGF-1 diminished suckling-induced increase in circulating IGF-1 levels, acute injection 5 min prior to the beginning of suckling did not have any effect. As we described above, the effects of IGF-1 on PRL release and long-loop negative feedback of GH axis likely acts on the gene expressional level, hence acute injection could not have any impact. Although there was a peak at $30 \mathrm{~min}$ in suckling-induced IGF-release in the continuously ACSF treated control group, following acute injections, IGF-1 level remained high at $60 \mathrm{~min}$, too, possibly due to stressrelated effects. PRL serum concentration also remained high, and this elevated PRL level could sustain the high level of IGF-1, even at $60 \mathrm{~min}$ after the beginning of suckling. This difference of the pattern could be due to the effect of stressful acute manipulations of the cerebrospinal fluid (CSF) via icv. injection, because stress could cause an additional induction of PRL release [34] Alternatively, other stress-induced hormones, such as corticosterone could contribute to the elevated IGF-1 level. In conclusion, we can declare that continuous icv. administration of IGF-1 diminishes suckling-induced IGF-1 release either by acting as a negative feedback in the somatotrop axis or by suppressing the suckling-induced PRL release.

\section{Conclusions}

In summary, we described the suckling-induced IGF-1 release, which peaked at $30 \mathrm{~min}$ after the beginning of suckling. The higher IGF1 level in the circulation could be beneficial, because IGF-1 can induce milk synthesis, PRL release from the pituitary, and may inhibit mammary cell apoptosis in the late lactation period. IGF-1 level correlated significantly with PRL raising the possibility that not only the sucklinginduced GH but also PRL may stimulate IGF-1 release into the circulation. Continuous central administration of IGF-1 diminished the suckling-induced surge of circulating IGF-1, suggesting that long-loop feedback control of GH axis could play a role in the regulation of suckling-induced IGF-1 release.

\section{Acknowledgements}

The work was supported by the Hungarian Academy of Sciences, the
National Research, Development and Innovation Office - NKFIH OTKA K116538, the KTIA_NAP_B_13-2-2014-0004, the KTIA_NAP_13-2-20170007, the National Research, Development and Innovation Office NKFIH NVKP_16-1-2016-0016, and the National Research, Development and Innovation Office - NKFIH VEKOP-2.3-15 Research Grants for AD, a Postdoctoral Research Fellowship and a Bolyai Fellowship of the Hungarian Academy of Sciences for MCs, and a ÚNKP New National Excellence Program of the Ministry of Human Capacities ÚNKP-17-3 for AHL. The authors also thank Nikolett Hanák, and Szilvia Deák for technical assistance, furthermore Balázs Istvánné and Éva Dobozi.

\section{Conflict of interests}

There are no conflicts of interests.

\section{Funding}

The work was supported by the Hungarian Academy of Sciences, the National Research, Development and Innovation Office - NKFIH OTKA K116538, the KTIA_NAP_B_13-2-2014-0004, the KTIA_NAP_13-2-20170007, the National Research, Development and Innovation Office NKFIH NVKP_16-1-2016-0016, and the National Research, Development and Innovation Office - NKFIH VEKOP-2.3-15 Research Grants for AD, a Postdoctoral Research Fellowship and a Bolyai Fellowship of the Hungarian Academy of Sciences for MCs, and a ÚNKP New National Excellence Program of the Ministry of Human Capacities ÚNKP-17-3 for AHL.

\section{References}

[1] R.J. Madon, D.M. Ensor, C.H. Knight, D.J. Flint, Effects of an antiserum to rat growth hormone on lactation in the rat, J. Endocrinol. 111 (1986) 117-123.

[2] T.D. Etherton, D.E. Bauman, Biology of somatotropin in growth and lactation of domestic animals, Physiol. Rev. 78 (1998) 745-761.

[3] S.R. Milsom, B.H. Breier, B.W. Gallaher, V.A. Cox, A.J. Gunn, P.D. Gluckman, Growth hormone stimulates galactopoiesis in healthy lactating women, Acta Endocrinol. 127 (1992) 337-343.

[4] J. Rushen, G. Foxcroft, A.M. De Passille, Nursing-induced changes in pain sensitivity, prolactin, and somatotropin in the pig, Physiol. Behav. 53 (1993) 265-270.

[5] L.C. Terry, A. Saunders, J. Audet, J.O. Willoughby, P. Brazeau, J.B. Martin, Physiologic secretion of growth hormone and prolactin in male and female rats, Clin. Endocrinol. (1977) 19s-28s (Oxf), 6 Suppl.

[6] H.J. Chen, G.P. Mueller, J. Meites, Effects of L-DOPA and Somatostatin on sucklinginduced release of prolactin and GH, Endocr. Res. Commun. 1 (1974) 283-291.

[7] W.B. Wehrenberg, R.C. Gaillard, Neuroendocrine mechanisms regulating growth hormone and prolactin secretion during lactation, Endocrinology 124 (1989) 464-467.

[8] C.G. Prosser, S.R. Davis, Milking frequency alters the milk yield and mammary blood flow response to intra-mammary infusion of insulin-like growth factor-I in the goat, J. Endocrinol. 135 (1992) 311-316.

[9] C.G. Prosser, S.R. Davis, V.C. Farr, P. Lacasse, Regulation of blood flow in the mammary microvasculature, J. Dairy Sci. 79 (1996) 1184-1197.

[10] D.L. Hadsell, S.G. Bonnette, A.V. Lee, Genetic manipulation of the IGF-I axis to regulate mammary gland development and function, J. Dairy Sci. 85 (2002) 365-377.

[11] S. Neuenschwander, A. Schwartz, T.L. Wood, C.T. Roberts Jr., L. Hennighausen, D. LeRoith, Involution of the lactating mammary gland is inhibited by the IGF system in a transgenic mouse model, J. Clin. Invest. 97 (1996) 2225-2232.

[12] D.J. Flint, C.H. Knight, Interactions of prolactin and growth hormone (GH) in the regulation of mammary gland function and epithelial cell survival, J. Mammary Gland Biol. Neoplasia 2 (1997) 41-48.

[13] L.J. Murphy, K. Tachibana, H.G. Friesen, Stimulation of hepatic insulin-like growth factor-I gene expression by ovine prolactin: evidence for intrinsic somatogenic activity in the rat, Endocrinology 122 (1988) 2027-2033.

[14] H. Abe, M.E. Molitch, J.J. Van Wyk, L.E. Underwood, Human growth hormone and somatomedin C suppress the spontaneous release of growth hormone in unanesthetized rats, Endocrinology 113 (1983) 1319-1324.

[15] M. Sato, L.A. Frohman, Differential effects of central and peripheral administration of growth hormone (GH) and insulin-like growth factor on hypothalamic GH-releasing hormone and somatostatin gene expression in GH-deficient dwarf rats, Endocrinology 133 (1993) 793-799.

[16] F.J. Steyn, V. Tolle, C. Chen, J. Epelbaum, Neuroendocrine regulation of growth hormone secretion, Compr. Physiol. 6 (2016) 687-735.

[17] A.H. Lékó, M. Cservenák, É.R. Szabó, J. Hanics, A. Alpár, Á. Dobolyi, Insulin-like growth factor I and its binding protein-3 are regulators of lactation and maternal 
responsiveness, Sci Rep 7 (2017) 3396.

[18] M. Cservenak, E.R. Szabo, I. Bodnar, A. Leko, M. Palkovits, G.M. Nagy, T.B. Usdin, A. Dobolyi, Thalamic neuropeptide mediating the effects of nursing on lactation and maternal motivation, Psychoneuroendocrinology 38 (2013) 3070-3084.

[19] M. Cservenak, I. Bodnar, T.B. Usdin, M. Palkovits, G.M. Nagy, A. Dobolyi, Tuberoinfundibular peptide of 39 residues is activated during lactation and participates in the suckling-induced prolactin release in rat, Endocrinology 151 (2010) 5830-5840.

[20] J. Escalada, F. Sanchez-Franco, B. Velasco, L. Cacicedo, Regulation of growth hormone $(\mathrm{GH})$ gene expression and secretion during pregnancy and lactation in the rat: role of insulin-like growth factor-I, Somatostatin, and GH-releasing hormone, Endocrinology 138 (1997) 3435-3443.

[21] S. Yakar, J.L. Liu, B. Stannard, A. Butler, D. Accili, B. Sauer, D. LeRoith, Normal growth and development in the absence of hepatic insulin-like growth factor I, Proc. Natl. Acad. Sci. U. S. A. 96 (1999) 7324-7329.

[22] I. Torres-Aleman, Toward a comprehensive neurobiology of IGF-I, Dev. Neurobiol. 70 (2010) 384-396.

[23] C.E. Grosvenor, L. Krulich, S.M. McCann, Depletion of pituitary concentration of growth hormone as a result of suckling in the lactating rat, Endocrinology 82 (1968) 617-619.

[24] D.E. English, S.M. Russell, L.S. Katz, C.S. Nicoll, Evidence for a role of the liver in the mammotrophic action of prolactin, Endocrinology 126 (1990) 2252-2256.

[25] M.J. Currie, N.S. Bassett, B.H. Breier, M. Klempt, S.H. Min, D.D. Mackenzie, S.N. McCutcheon, P.D. Gluckman, Differential effects of maternal ovine placental lactogen and growth hormone (GH) administration on GH receptor, insulin-like growth factor (IGF)-1 and IGF binding protein-3 gene expression in the pregnant and fetal sheep, Growth Regul. 6 (1996) 123-129.

[26] I. El Khattabi, C. Remacle, B. Reusens, The regulation of IGFs and IGFBPs by prolactin in primary culture of fetal rat hepatocytes is influenced by maternal malnutrition, Am. J. Physiol. Endocrinol. Metab. 291 (2006) E835-842.

[27] W.S. Cohick, M.A. McGuire, D.R. Clemmons, D.E. Bauman, Regulation of insulinlike growth factor-binding proteins in serum and lymph of lactating cows by somatotropin, Endocrinology 130 (1992) 1508-1514.

[28] S. Fruchtman, D.C. McVey, R.J. Borski, Characterization of pituitary IGF-I receptors: modulation of prolactin and growth hormone, Am. J. Physiol. Regul. Integr. Comp. Physiol. 283 (2002) R468-476.

[29] S. Fruchtman, L. Jackson, R. Borski, Insulin-like growth factor I disparately regulates prolactin and growth hormone synthesis and secretion: studies using the teleost pituitary model, Endocrinology 141 (2000) 2886-2894.

[30] D.L. Hadsell, N.M. Greenberg, J.M. Fligger, C.R. Baumrucker, J.M. Rosen, Targeted expression of des(1-3) human insulin-like growth factor I in transgenic mice influences mammary gland development and IGF-binding protein expression, Endocrinology 137 (1996) 321-330.

[31] J. Yang, J.J. Kennelly, V.E. Baracos, The activity of transcription factor Stat 5 responds to prolactin, growth hormone, and IGF-I in rat and bovine mammary explant culture, J. Anim. Sci. 78 (2000) 3114-3125.

[32] G.A. Werther, A. Hogg, B.J. Oldfield, M.J. McKinley, R. Figdor, F.A. Mendelsohn, Localization and characterization of insulin-like growth factor-I receptors in rat brain and pituitary gland using in vitro autoradiography and computerized densitometry* a distinct distribution from insulin receptors, J. Neuroendocrinol. 1 (1989) 369-377.

[33] C.A. Jaffe, R.D. Friberg, A.L. Barkan, Suppression of growth hormone (GH) secretion by a selective GH-releasing hormone (GHRH) antagonist. Direct evidence for involvement of endogenous GHRH in the generation of GH pulses, J. Clin. Invest. 92 (1993) 695-701.

[34] M.E. Freeman, B. Kanyicska, A. Lerant, G. Nagy, Prolactin: structure, function, and regulation of secretion, Physiol. Rev. 80 (2000) 1523-1631. 